\title{
鹿児島県におけるサワガニの 体色変異とその分布
}

\author{
鈴 木 廣 志・津 田英 治
}

（鹿児島大学水産学部）

\author{
Study on the Color Variation and Distribution \\ of a Freshwater Crab, Geothelphusa dehaani \\ (WhiTe), in Kagoshima Prefecture \\ HIROSHI SUZUKI and EIJI TSUDA
}

\begin{abstract}
SUZUKI, HIROSHI and EIJI TSUDA (Faculty of Fisheries, Kagoshima University). 1991. Study on the Color Variation and Distribution of a Freshwater Crab, Geothelphusa dehaani (WHITE), in Kagoshima Prefecture. Benthos Research (Bull. Jap. Assoc. Benthology), 41 : 37-46.

Specimens of the freshwater crab Geothelphusa dehaani (WHITE) were collected at 60 points of Kagoshima Prefecture to study the color variations appeared on the carapace, cheliped, and ambulatory legs from May to September of 1989. The color variations were fundamentally distinguished into three types: Blue Type, Red Type, and Brown Type. The color of young crabs were Brown Type and changed into Blue Type or Red Type when the crabs reached more than $14 \mathrm{~mm}$ in carapace width. Red Type crabs were distributed to the north of Kamino River, Satsuma Peninsula and Kimotsuki River, Oosumi Peninsula, while Blue Type crabs were distributed to the south of these rivers. The predominant carotenoids were lutein, astaxanthin, astaxanthin diester, and astaxanthin monoester in the Red Type crabs, while in the Blue Type crabs they were $\beta$-carotene and lutein.
\end{abstract}

はじめに

日本本土に広く分布する，サワガニ Geothelphusa dehaani (WHITE) には, 古くから体色変異のあるこ とが知られている。一寸木 $(1976,1980)$ は関東地方 および本州北部におけるサワガニの体色変異について 研究し, 本種の体色を青みがかった色彩, 赤みがかっ た色彩，茶色がかった色彩の 3 型に大別し，それぞれ の体色型の分布にはほとんど重複が認められないこと

1991年 3 月 11 日受付 : 1991年 6 月 14 日受理
を明らかにした。菅原・蒲生（1984）は，体色変異に ともなって雄の第一腹肢の形態にも若干の相違が認め られ, 本種の体色変異は地方集団間の遺伝的分化を示 唆する形質であると報告している。また，NAKA JIMA \& MASUDA (1985) は, 胸脚の毛数にも体色間の 違いがあることを報告している.

しかしながら,これらの研究では点在する地方集団 間の比較を行っているため, 各体色型の分布境界地域 の特定および特徵など，末だ明らかにされていない点 がある.サワガニの多色現象を生物地理学的視点から 研究するためには, ある一定の地域内における体色変 
異とその分布等の詳細な調査を行う必要がある. 本研 究では, 鹿児島県におけるサワガニの体色変異および その地理的分布等を明らかにすることを目的とした。

\section{材料と方法}

調査は1989年 5 月 9 日から 9 月 12 日まで, 随時, 鹿 児島県内21水系60ヶ所で行った (Fig. 1)。 サワガニが 清流域に生息することを考慮して, 各河川の起点近く を採集地点とし, 主に10分間, 川辺や石の裹などをた んねんに探しながら手取りで採集した。採集と同時に，
採集地点の川幅, 周辺の植物, 川床の底質等について 目視観察し，その概略を記録した。その際，流れの速 さは slow (秒速数 $\mathrm{cm}$ 末満), fast (秒速数 $\mathrm{cm}$ 以上数 $10 \mathrm{~cm}$ 末満), rapid (秒速数十 $\mathrm{cm}$ 以上) の 3 段階で表 し, 明るさはdark (採集地点の林冠に間隙がほとんど 無い), shade (林冠の間隙が50\%未満), bright (林冠 の間隙が $50 \%$ 以上）の 3 段階で表現した。 また, 堆積 物の量は rare(ほとんど無い), little(堆積物の厚さ10 $\mathrm{mm}$ 未満), much（厚さ $10 \mathrm{~mm}$ 以上）の 3 段階で表現 し，標高は25,000分の 1 の地図から読みとった。

個体の体色は, 一寸木（1976）の記載を参考にして

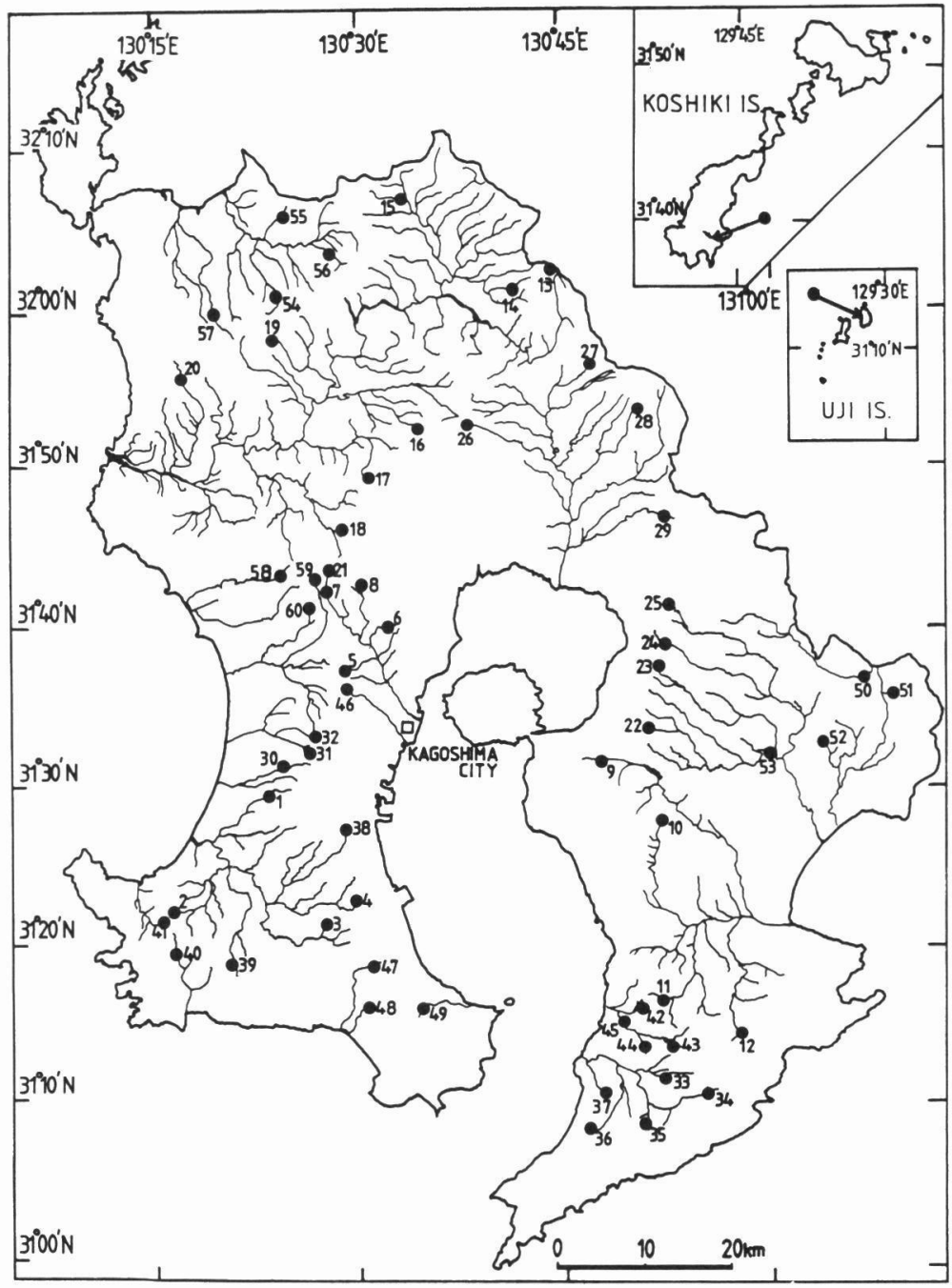

Fig. 1 Map showing the sampling stations () in Kagoshima Prefecture, Shimokoshiki Is. and Uji Is. 
甲面および歩脚の色によって類型化した．体色の記録 と同時に甲幅をノギスで $0.05 \mathrm{~mm} の$ 精度で計測し，性 も記録した。本報告では，1989年の調査で採集された 標本に加え，1986年 5 月11日に宇治群島家島で採集し た標本，および1987年 6 月 4 日に下憎島で採集した標 本も用いた。

各体色のカロテノイド色素組成は, 薄層クロマトグ ラフィー法によって分離分析した。分析には, 各体色 型の雌雄それぞれ 1 個体を用いた。

採集地点における生息数を相対的に評価するために， 採集個体数を単位努力量当りの個体数（個体数/10分/ 人）に換算し，相対生息数として表わした。

\section{結＼cjkstart果}

\section{1. 鹿児島県に出現する体色型}

サワガニの体色変異は甲背面および歩脚において明 瞭であり，鹿児島県で採集された標本は大きく 3 つの 型に区別することができた（Fig. 2).すなわち， 赤色型：甲背面の前半部は黒色, 後半部および歩脚 が朱色である個体,

青色型：甲背面全体が青色もしくは前半部が青く後 半部が淡黄色, 歩脚が淡黄色の個体,
茶色型：甲背面が褐色もしくは紫色，歩脚も同様の 体色を呈する個体

の 3 型である.

赤色型の個体は，甲背面および歩脚における斑紋の 存在に違いが認められ，この形質によりさらに 3 覀型 に分けることができた。すなおち，斑紋がまったく無 い個体 (赤色 1 型)，歩脚のみに斑紋がある個体 (赤色 2 型)，甲背面と歩脚に斑紋がある個体 (赤色 3 型) の 3 西型である。また，茶色型の個体でも，甲背面およ び歩脚が紫色の個体(茶色 1 型)，甲背面抢よび歩脚が 黄褐色もしくは厕褐色の個体(茶色 2 型)，茶色 2 型の 体色に赤みが加わった個体(茶色 3 型)，および前半部 が暗褐色で，後半部および歩脚が淡黄色の個体（茶色 4 型）の 4 覀型に分けることができた。

\section{2, 各体色型の色素組成}

標本各個体の単位湿重量当たりの各カロテノイド色 素の含有量をみると，ルテインは青色型抢よび茶色 4 型が $2.66 \mu \mathrm{g} / \mathrm{g}$ から $14.02 \mu \mathrm{g} / \mathrm{g}$ の範讲で, 赤色型およ び茶色 1 型が $4.09 \mu \mathrm{g} / \mathrm{g}$ から $10.12 \mu \mathrm{g} / \mathrm{g}$ の範囲であっ た(Table 1)。アスタキサンチンの含有量は, 青色型 および茶色 4 型では $3.92 \mu \mathrm{g} / \mathrm{g}$ 以下であったが，赤色 型および茶色 1 型では $5.31 \mu \mathrm{g} / \mathrm{g}$ から $9.04 \mu \mathrm{g} / \mathrm{g}$ の範

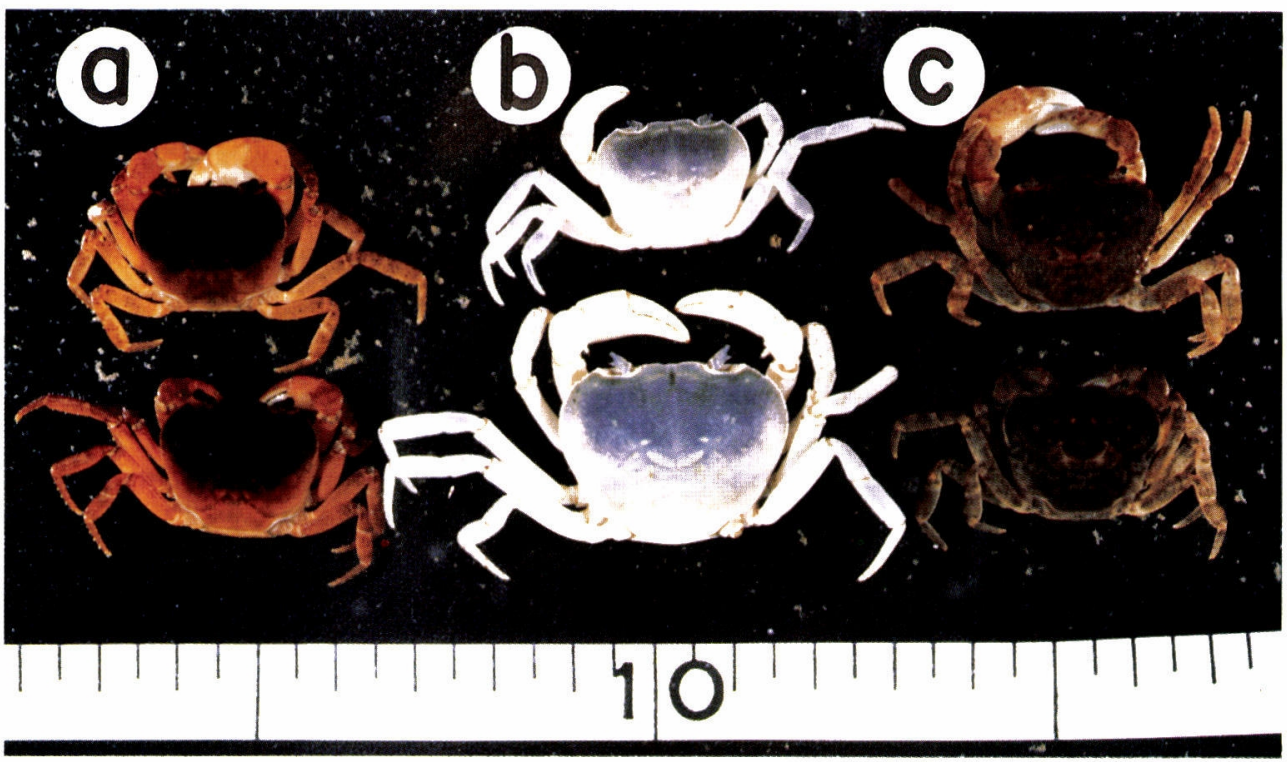

Fig. 2 Three types of color variations of Geothelphusa dehaani, captured in Kagoshima Prefecture. a: Red Type, b: Blue Type, and c: Brown Type. The smallest unit of scale indicates $5.0 \mathrm{~mm}$. 
Table 1 Carotenoid contents of whole body in each color-type crab. For color-type, see the text. Unit : $\mu \mathrm{g} / \mathrm{g}$

\begin{tabular}{l|rrrrrrrr}
\hline $\begin{array}{c}\text { color } \\
\text { type }\end{array}$ & sex & $\begin{array}{l}\text { carapace } \\
\text { width }(\mathrm{mm})\end{array}$ & $\begin{array}{l}\text { lutein } \\
\text { fraction }\end{array}$ & $\begin{array}{l}\text { astaxanthin } \\
\text { fraction }\end{array}$ & $\begin{array}{l}\text { asta-mono } \\
\text { fraction }\end{array}$ & $\begin{array}{l}\text { asta-di } \\
\text { fraction }\end{array}$ & $\begin{array}{l}\beta \text {-carotene } \\
\text { fraction }\end{array}$ & others \\
\hline BLUE & male & 21.15 & 2.66 & trace & 0.00 & 0.00 & 4.94 & trace \\
BLUE & female & 22.10 & 6.83 & trace & 0.00 & 0.00 & 2.61 & 2.06 \\
BROWN 4 & male & 17.20 & 4.49 & 1.43 & 0.00 & 0.00 & 2.80 & 2.58 \\
BROWN 4 & female & 20.30 & 14.02 & 3.92 & 0.97 & 0.00 & 1.90 & 3.51 \\
\hline \multirow{2}{*}{ RED } & male & 24.40 & 4.09 & 9.04 & 2.88 & 5.51 & 0.47 & 2.77 \\
RED & female & 20.90 & 10.01 & 5.31 & 1.80 & 10.90 & 0.60 & 6.57 \\
BROWN 1 & male & 24.70 & 6.25 & 7.38 & 2.75 & 8.04 & 1.49 & 3.33 \\
BROWN 1 & female & 21.20 & 10.12 & 7.49 & 4.26 & 9.88 & 0.56 & 4.23 \\
\hline
\end{tabular}

囲であった・アスタキサンチン・モノエステル（astamono）の含有量は，青色型および茶色 4 型では0.97 $\mu \mathrm{g} / \mathrm{g}$ 以下で, ほとんど検出できなかったが, 赤色型お よび茶色 1 型では $1.80 \mu \mathrm{g} / \mathrm{g}$ から $4.26 \mu \mathrm{g} / \mathrm{g}$ の範囲で あった.アスタキサンチン・ジエステル（asta-di）の

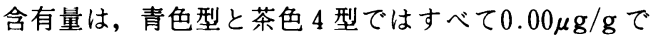
あったのに対し，赤色型および茶色 1 型では $5.51 \mu \mathrm{g} / \mathrm{g}$ から $10.90 \mu \mathrm{g} / \mathrm{g}$ の高い值を示した。一方, $\beta$-カロテン の含有量は青色型および茶色 4 型では $1.90 \mu \mathrm{g} / \mathrm{g}$ から $4.94 \mu \mathrm{g} / \mathrm{g}$ の高い值を示したが，赤色型および茶色 1 型では $0.47 \mu \mathrm{g} / \mathrm{g}$ から $1.49 \mu \mathrm{g} / \mathrm{g}$ の範囲であった。

以上のように，青色型と茶色 4 型におけるアスタキ サンチン, アスタキサンチン・モノエステル，および アスタキサンチン・ジエステルの含有量は, 赤色型と 茶色 1 型の含有量にくらべて少ないかもしくは含有さ れていなかった。これに対し, 青色型と茶色 4 型にお ける $\beta$-カロテンの含有量は, 赤色型と茶色 1 型の含有 量にくらべて多い傾向が認められた.

\section{3. 各体色型の分布, 相対生息数, および生息環境}

鹿児島県に出現した 3 つの体色型の分布をみると， 鹿児島県北部の米之津川水系, 野田川水系, 川内川水 系, 天降川水系, 大淀川水系および鹿児島県東部の安 楽川水系では赤色型が生息していた（Table 2, Fig. 3). 薩摩半島の甲突川水系, 神之川水系の神之川と野 田川では赤色型が出現したが，同じ神之川水系の下谷 口川, 新川水系, 伊作川水系, 永吉川水系, 万之瀬川 水系, 花渡川水系, 大浦川水系, 港川水系, 馬渡川水 系では青色型が出現した. 大隅半島では菱田川水系と
肝属川水系の串良川と肝属川において赤色型が出現し たが, 肝属川水系の苫野川, 雄川水系の紫立川と馬場 川, 神之川水系では青色型が出現した。 茶色型は大隅 半島の雄川水系の馬場川および薩摩半島の甲突川水系 の犬追川をのぞいたすべての河川で出現した，甲突川 水系の犬追川ではサワガニの生息を確認することがで きなかった. (Table 2).

以上のように, 各体色型の分布は, 薩摩半島では甲 突川水系の甲突川と新川水系の新川および神之川水系 の野田川と同水系の下谷口川を境に, 大隅半島では肝 属川水系の肝属川と同水系の苫野川を境にして分かれ， 北には赤色型が分布し, 南には青色型が分布していた

(Fig. 3). 茶色型は調查地域全域にわたって分布して いた。また，宇治群島家島の個体は青色型であったの に対し，下甑島の個体は赤色型であった。

各体色型の平均相対生息数（個体/10分/人）と標準

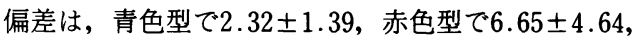

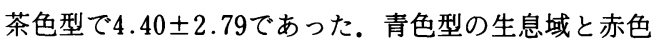

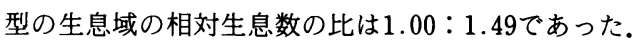
また, 青色型の生息域内における青色型と茶色型の相

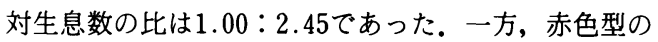
生息域内における赤色型と茶色型の相対生息数の比は 1.75：1.00であった.このように, 赤色型と青色型の 生息域間の相対生息数には大きな差はなかったが, 各 体色型の相対生息数は, 赤色型, 茶色型, 青色型の順 に少なかった。

各体色型の生息環境をみると, 赤色型生息域内の 33 地点の川幅は0.3〜 7m の範囲で, 標高は90〜 745m の 範囲であった (Table 3). 33点のうち18地点では流れ 
Table 2 List of color variations of Geothelphusa dehaani obtained from each station. BL, RE, and BR indicate Blue Type, Red Type, and Brown Type, respectively

\begin{tabular}{|c|c|c|c|c|}
\hline Stn. & River & River branch & Peninsula & Color \\
\hline 1 & \multirow{4}{*}{ Manose R. } & Hori & \multirow{4}{*}{ Satsuma } & $\mathrm{BL}, \mathrm{BR}$ \\
\hline 2 & & Higo & & $\mathrm{BL}, \mathrm{BR}$ \\
\hline 3 & & Nagasato & & $\mathrm{BL}, \mathrm{BR}$ \\
\hline 4 & & Hutokoro & & $\mathrm{BL}, \mathrm{BR}$ \\
\hline 5 & \multirow[t]{4}{*}{ Koutsuki R. } & Inuoi & \multirow[t]{4}{*}{ Satsuma } & \\
\hline 6 & & Hishijima & & $\mathrm{RE}, \mathrm{BR}$ \\
\hline 7 & & Koutsuki & & $\mathrm{RE}, \mathrm{BR}$ \\
\hline 8 & & Miyawaki & & $\mathrm{RE}, \mathrm{BR}$ \\
\hline 9 & \multirow[t]{4}{*}{ Kimotsuki R. } & Kushira & \multirow[t]{4}{*}{ Oosumi } & $\mathrm{RE}, \mathrm{BR}$ \\
\hline 10 & & Kimotsuki & & $\mathrm{RE}, \mathrm{BR}$ \\
\hline 11 & & Tomano & & $\mathrm{BL}, \mathrm{BR}$ \\
\hline 12 & & Hutamata & & \\
\hline 13 & \multirow[t]{8}{*}{ Sendai $R$. } & Shira & \multirow[t]{8}{*}{ Main land } & $\mathrm{RE}, \mathrm{BR}$ \\
\hline 14 & & Shin & & $\mathrm{RE}, \mathrm{BR}$ \\
\hline 15 & & Kosendai & & $\mathrm{RE}, \mathrm{BR}$ \\
\hline 16 & & Tsuzura & & $\mathrm{RE}, \mathrm{BR}$ \\
\hline 17 & & Kubuki & & $\mathrm{RE}, \mathrm{BR}$ \\
\hline 18 & & Hiwaki & & $\mathrm{RE}, \mathrm{BR}$ \\
\hline 19 & & Oousu & & $\mathrm{RE}, \mathrm{BR}$ \\
\hline 20 & & Takanari & & $\mathrm{RE}, \mathrm{BR}$ \\
\hline 21 & Koutsuki R. & Koutsuki & Satsuma & $\mathrm{RE}, \mathrm{BR}$ \\
\hline 22 & \multirow{4}{*}{ Hishida R. } & Uratani & \multirow{4}{*}{ Oosumi } & $\mathrm{RE}, \mathrm{BR}$ \\
\hline 23 & & Tsukino & & $\mathrm{RE}, \mathrm{BR}$ \\
\hline 24 & & Mae & & $\mathrm{RE}, \mathrm{BR}$ \\
\hline 25 & & Karei & & $\mathrm{RE}, \mathrm{BR}$ \\
\hline 26 & \multirow[t]{4}{*}{ Amori R. } & Nosaka & \multirow[t]{4}{*}{ Main land } & $\mathrm{RE}, \mathrm{BR}$ \\
\hline 27 & & Tsukuda & & \\
\hline 28 & & Nakatsu & & $\mathrm{RE}, \mathrm{BR}$ \\
\hline 29 & & Miyakoda & & $\mathrm{RE}, \mathrm{BR}$ \\
\hline 30 & Izaku R. & Izaku & Satsuma & $\mathrm{BL}, \mathrm{BR}$ \\
\hline 31 & Nagayoshi R. & Hutamata & Satsuma & $\mathrm{BL}, \mathrm{BR}$ \\
\hline 32 & Satsumakamino R. & Shimotanikuchi & Satsuma & $\mathrm{BL}, \mathrm{BR}$ \\
\hline 33 & \multirow[t]{5}{*}{ O R. } & $\begin{array}{l}\text { Hutokoro } \\
\text { lo }\end{array}$ & \multirow[t]{5}{*}{ Oosumi } & \\
\hline 34 & & Shibatate & & $\mathrm{BL}, \mathrm{BR}$ \\
\hline 35 & & Oohuji & & $\mathrm{BR}$ \\
\hline 36 & & Akase & & $\mathrm{BR}$ \\
\hline 37 & & Baba & & BL \\
\hline 38 & \multirow[t]{2}{*}{ Manose R. } & Nozaki & \multirow[t]{2}{*}{ Satsuma } & $\mathrm{BL}, \mathrm{BR}$ \\
\hline 39 & & Ootani & & $\mathrm{BL}, \mathrm{BR}$ \\
\hline 40 & Kedo $\mathrm{R}$. & Kedo & Satsuma & $\mathrm{BL}, \mathrm{BR}$ \\
\hline 41 & Ooura R. & Ooura & Satsuma & $\mathrm{BL}, \mathrm{BR}$ \\
\hline 42 & Oosumikamino R. & Kamino & Oosumi & $\mathrm{BL}, \mathrm{BR}$ \\
\hline 43 & & Kamino & & $\mathrm{BL}, \mathrm{BR}$ \\
\hline 44 & & Kamino & & $\mathrm{BL}, \mathrm{BR}$ \\
\hline 45 & & Kamino & & $\mathrm{BL}, \mathrm{BR}$ \\
\hline 46 & Shin R. & Shin & Satsuma & $\mathrm{BL}, \mathrm{BR}$ \\
\hline 47 & Mawatari R. & Mawatari & Satsuma & $\mathrm{BL}, \mathrm{BR}$ \\
\hline 48 & & Takatori & & $\mathrm{BL}, \mathrm{BR}$ \\
\hline 49 & Minato $\mathrm{R}$. & Minato & Satsuma & $\mathrm{BL}, \mathrm{BR}$ \\
\hline 50 & Ooyodo R. & Ooyodo & Main land & $\mathrm{RE}, \mathrm{BR}$ \\
\hline 51 & Anraku R. & Anraku & Main land & $\mathrm{RE}, \mathrm{BR}$ \\
\hline 52 & & Motomura & & $\mathrm{RE}, \mathrm{BR}$ \\
\hline 53 & Hishida R. & Ootori & Oosumi & RE, BR \\
\hline 54 & Komenotsu R. & Jyoudan & Main land & $\mathrm{RE}, \mathrm{BR}$ \\
\hline 55 & & Jikutani & & $\mathrm{RE}, \mathrm{BR}$ \\
\hline 56 & & Shirakisendai & & $\mathrm{RE}, \mathrm{BR}$ \\
\hline 57 & Noda R. & Takaono & Main land & $\mathrm{RE}, \mathrm{BR}$ \\
\hline 58 & Yahusa R. & Yahusa & Satsuma & RE, BR \\
\hline 59 & Satsumakamino $R$. & Kamino & Satsuma & RE, BR \\
\hline 60 & & Noda & & $\mathrm{RE}, \mathrm{BR}$ \\
\hline
\end{tabular}




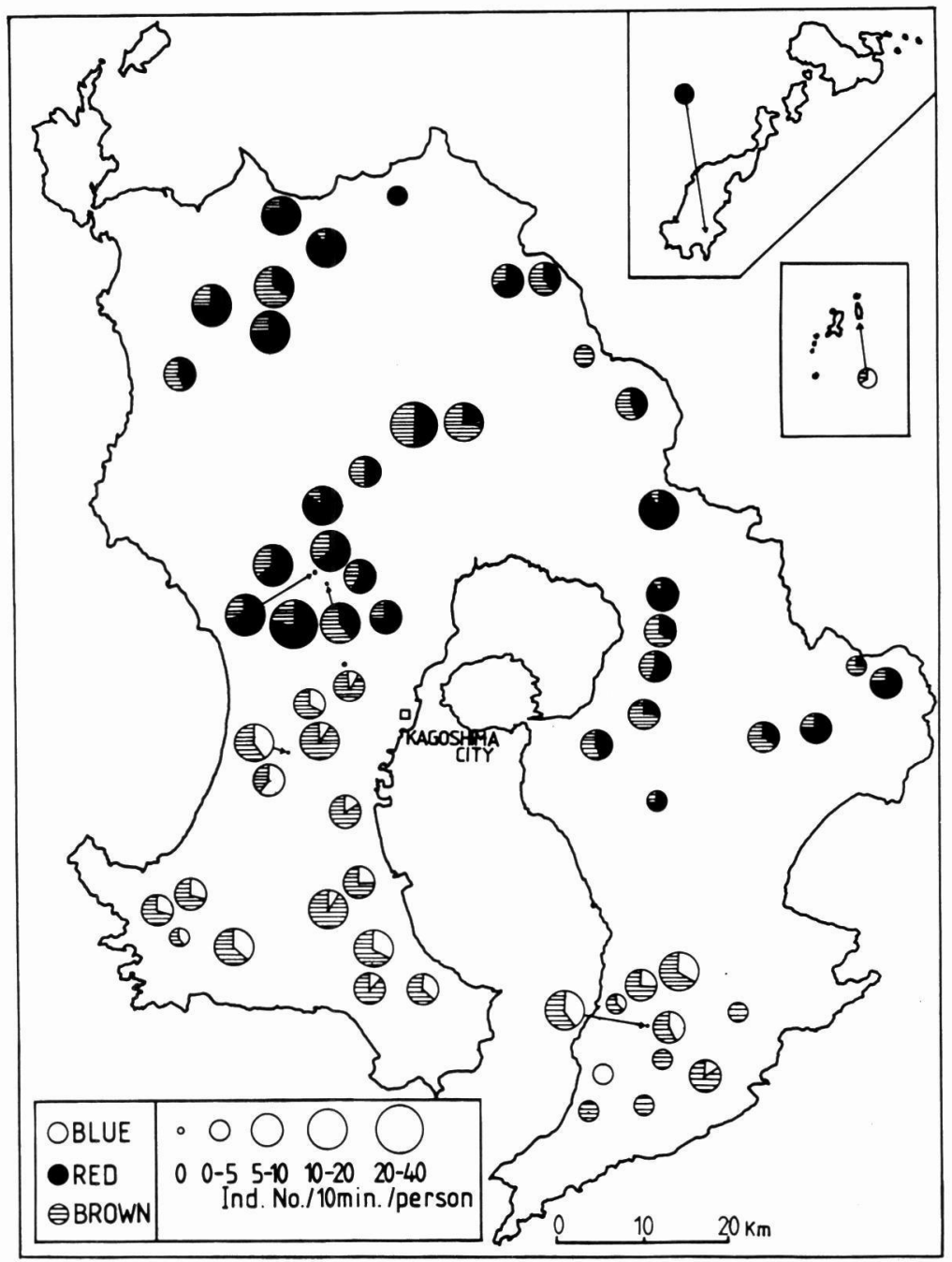

Fig. 3 Map showing distributions of three color types of Geothelphusa dehaani.

が速く，12地点ではゆるやかであった．周辺の植物に は全般に広葉樹や竹が多くみられた。川床の底質は半 数以上の地点で転石と碟が主であった. 周辺の明るさ をみると明るい地点と暗い地点がほぼ同数認められた。 川床の堆積物の厚さは22地点において $10 \mathrm{~mm}$ を超え た.

青色型生息域内の 26地点の川幅は0.5〜 $5 \mathrm{~m} の$ 範囲 で，標高は40〜 540m の範囲であった(Table 4).この うち10地点では流れが速く, 15地点ではゆるやかであ った。周辺の植物は赤色型の生息地点と同様に広葉樹
や竹が多かった１0地点の川床の底質状態は転石と碟 であった，明るさをみると，中程度の地点と暗い地点 がほぼ同数であった。川床の堆積物の厚さは17地点に おいて $10 \mathrm{~mm}$ を超えた。

\section{4. 体色と成長}

成長と体色との関係をみるために，赤色型の生息域 および青色型の生息域別に各体色型の甲幅組成を検討 した (Figs. 4, 5).

赤色型生息域の雄においては, 茶色 2 型および茶色 
Table 3 Environmental characteristics of habitat of Red Type crabs

\begin{tabular}{|c|c|c|c|c|c|c|c|}
\hline Stn. & $\begin{array}{l}\text { River } \\
\text { width }(\mathrm{m})\end{array}$ & $\begin{array}{l}\text { Current } \\
\text { velocity }\end{array}$ & Vegetation* & $\begin{array}{l}\text { River } \\
\text { bottom** }\end{array}$ & Visibility & $\begin{array}{l}\text { Amount of } \\
\text { soil }\end{array}$ & $\begin{array}{c}\text { Elevation } \\
\text { (m) }\end{array}$ \\
\hline 6 & 0.4 & slow & $\mathrm{B}, \mathrm{L}$ & $\mathrm{Co}, \mathrm{Si}$ & dark & much & 120 \\
\hline 7 & 2.5 & fast & $\mathrm{B}$ & $\mathrm{R}$ & bright & little & 150 \\
\hline 8 & 2 & fast & $\mathrm{G}, \mathrm{L}$ & Co & bright & little & 150 \\
\hline 9 & 3 & rapid & $\mathrm{L}$ & $\mathrm{B}, \mathrm{G}, \mathrm{Co}$ & dark & rare & 300 \\
\hline 10 & 3 & slow & $\mathrm{B}, \mathrm{L}$ & $\mathrm{R}, \mathrm{F}$ & bright & much & 100 \\
\hline 13 & 1.5 & rapid & $\mathrm{S}, \mathrm{C}, \mathrm{R}$ & Co, $\mathrm{P}$ & dark & much & 310 \\
\hline 14 & 1 & rapid & $\mathrm{L}$ & Co, $\mathrm{P}$ & dark & much & 270 \\
\hline 15 & 3 & rapid & $\mathrm{L}$ & Co, $\mathrm{P}$ & dark & rare & 315 \\
\hline 16 & 4 & rapid & $\mathrm{F}, \mathrm{L}, \mathrm{R}$ & $\mathrm{Co}, \mathrm{P}$ & shade & rare & 320 \\
\hline 17 & 3 & rapid & $\mathrm{B}, \mathrm{L}$ & Co, $\mathrm{P}$ & bright & little & 330 \\
\hline 18 & 0.5 & slow & $\mathrm{G}, \mathrm{S}$ & Co, $\mathrm{P}$ & shade & rare & 150 \\
\hline 19 & 2.5 & slow & $\mathrm{B}, \mathrm{F}, \mathrm{L}$ & Co, $\mathrm{P}$ & dark & rare & 240 \\
\hline 20 & 1 & rapid & $\mathrm{C}, \mathrm{F}, \mathrm{S}$ & Co, $\mathrm{P}$ & dark & much & 120 \\
\hline 21 & 1 & rapid & $\mathrm{G}, \mathrm{S}$ & Co, $\mathrm{P}$ & dark & much & 395 \\
\hline 22 & 1 & slow & $\mathrm{L}$ & $\mathrm{R}, \mathrm{Co}, \mathrm{Si}$ & dark & much & 360 \\
\hline 23 & 3 & rapid & $\mathrm{B}, \mathrm{S}$ & Co, $\mathrm{P}$ & shade & much & 335 \\
\hline 24 & 4 & rapid & $\mathrm{G}, \mathrm{S}$ & Co, $\mathrm{P}$ & bright & much & 295 \\
\hline 25 & 0.5 & slow & $\mathrm{B}, \mathrm{L}$ & Co, $\mathrm{P}$ & dark & much & 325 \\
\hline 26 & 0.3 & slow & $\mathrm{B}, \mathrm{L}$ & $\mathrm{R}, \mathrm{Co}$ & dark & much & 340 \\
\hline 27 & 3 & rapid & $\mathrm{L}$ & $\mathrm{Co}, \mathrm{P}, \mathrm{Si}$ & bright & little & 745 \\
\hline 28 & 1 & rapid & $F, G$ & $\mathrm{R}, \mathrm{Co}$ & shade & much & 610 \\
\hline 29 & 2 & rapid & $\mathrm{G}, \mathrm{L}, \mathrm{R}$ & $\mathrm{Co}, \mathrm{P}$ & bright & rare & 300 \\
\hline 50 & 7 & rapid & $\mathrm{L}, \mathrm{R}$ & $\mathrm{Co}, \mathrm{Si}, \mathrm{Cl}$ & bright & much & 210 \\
\hline 51 & 3 & rapid & C, L & Co & bright & much & 210 \\
\hline 52 & 0.5 & slow & B & Co & dark & much & 100 \\
\hline 53 & 3 & slow & $\mathrm{L}$ & $\mathrm{R}, \mathrm{Co}$ & dark & rare & 90 \\
\hline 54 & 4 & fast & $\mathrm{C}, \mathrm{G}, \mathrm{L}$ & Co, $\mathrm{P}$ & bright & much & 270 \\
\hline 55 & 4 & rapid & $\mathrm{L}$ & $\mathrm{Co}, \mathrm{P}, \mathrm{Si}$ & bright & much & 120 \\
\hline 56 & 0.5 & slow & $F, L, S$ & $\mathrm{Co}, \mathrm{P}, \mathrm{Si}$ & dark & much & 150 \\
\hline 57 & 5 & rapid & $\mathrm{B}, \mathrm{L}$ & $\mathrm{Co}, \mathrm{P}, \mathrm{Si}$ & bright & much & 170 \\
\hline 58 & 2 & slow & $\mathrm{L}$ & $\mathrm{Co}, \mathrm{P}, \mathrm{Si}$ & dark & much & 230 \\
\hline 59 & 1 & slow & $\mathrm{G}, \mathrm{R}$ & $\mathrm{Co}, \mathrm{Si}$ & bright & much & 200 \\
\hline 60 & 3 & rapid & $\mathrm{L}$ & $\mathrm{Co}, \mathrm{P}, \mathrm{Si}$ & dark & much & 200 \\
\hline
\end{tabular}

* B : bamboo, C : conifer, F : fern, G: grass, L : latifoliate tree, M : moss, $\mathrm{R}$ : rice field, $\mathrm{S}$ : shrub

${ }^{* *} \mathrm{R}$ : rock, $\mathrm{B}$ : boulder, Co : cobble, $\mathrm{P}$ : pebble, $\mathrm{G}$ : granule, $\mathrm{S}$ : sand, $\mathrm{F}$ : fine sand, $\mathrm{Si}$ : silt, $\mathrm{Cl}$ : clay. 
Table 4 Environmental characteristics of habitat of Blue Type crabs

\begin{tabular}{|c|c|c|c|c|c|c|c|}
\hline Stn. & $\begin{array}{l}\text { River } \\
\text { width (m) }\end{array}$ & $\begin{array}{l}\text { Current } \\
\text { Velocity }\end{array}$ & Vegetation* & $\begin{array}{l}\text { River } \\
\text { bottom** }\end{array}$ & Visibility & $\begin{array}{l}\text { Amount } \\
\text { of soil }\end{array}$ & $\begin{array}{c}\text { Elevation } \\
(\mathrm{m})\end{array}$ \\
\hline 1 & 5 & rapid & $\mathrm{L}$ & $\mathrm{R}$ & shade & much & 40 \\
\hline 2 & 2 & slow & $\mathrm{L}$ & Co, $\mathrm{P}$ & dark & little & 120 \\
\hline 3 & 0.5 & slow & $\mathrm{B}, \mathrm{C}, \mathrm{S}$ & $\mathrm{P}, \mathrm{S}$ & shade & much & 140 \\
\hline 4 & 3 & rapid & $\mathrm{L}$ & G, So & shade & rare & 220 \\
\hline 11 & 5 & fast & $\mathrm{L}$ & $\mathrm{B}, \mathrm{Co}, \mathrm{F}$ & shade & much & 90 \\
\hline 12 & 4 & rapid & $\mathrm{L}$ & Co, G & shade & rare & 390 \\
\hline 30 & 3 & slow & $\mathrm{B}, \mathrm{C}$ & Co, $\mathrm{P}$ & dark & much & 100 \\
\hline 31 & 1 & slow & $\mathrm{R}, \mathrm{S}$ & Co, $\mathrm{P}$ & dark & rare & 130 \\
\hline 32 & 0.5 & slow & C, L, S & Co, $\mathrm{P}$ & dark & much & 210 \\
\hline 33 & 2 & rapid & C, L & $\mathrm{P}, \mathrm{S}$ & dark & rare & 270 \\
\hline 34 & 2 & rapid & $\mathrm{L}$ & Co, $\mathrm{S}$ & dark & little & 405 \\
\hline 35 & 1 & rapid & C, $\mathrm{M}$ & $\mathrm{R}, \mathrm{Co}, \mathrm{S}$ & dark & much & 515 \\
\hline 36 & 3 & rapid & $\mathrm{L}, \mathrm{M}$ & $\mathrm{Co}, \mathrm{S}$ & dark & much & 540 \\
\hline 37 & 1 & slow & B, C & $\mathrm{Co}, \mathrm{Si}$ & dark & much & 270 \\
\hline 38 & 1.5 & slow & $\mathrm{C}, \mathrm{G}, \mathrm{L}$ & Co, $\mathrm{P}$ & dark & much & 340 \\
\hline 39 & 0.5 & slow & B, L & Co, $\mathrm{P}$ & dark & much & 123 \\
\hline 40 & 2 & slow & B, F & $\mathrm{R}, \mathrm{Co}, \mathrm{P}$ & bright & much & 270 \\
\hline 41 & 2 & slow & B, C, L & $\mathrm{P}$ & bright & rare & 60 \\
\hline 42 & 3 & rapid & $\mathrm{L}, \mathrm{M}$ & Co & dark & rare & 180 \\
\hline 43 & 1 & slow & $\mathrm{C}, \mathrm{G}, \mathrm{R}$ & $\mathrm{Co}, \mathrm{Si}$ & shade & much & 140 \\
\hline 44 & 3 & slow & $\mathrm{B}, \mathrm{G}$ & $\mathrm{R}, \mathrm{Co}, \mathrm{Si}$ & shade & much & 180 \\
\hline 45 & 2 & slow & $F, G$ & Co, $\mathrm{P}$ & bright & much & 40 \\
\hline 46 & 0.5 & slow & G, L & Co, P, Si & dark & much & 70 \\
\hline 47 & 4 & rapid & $\mathrm{B}, \mathrm{L}$ & Co, $\mathrm{P}$ & shade & much & 310 \\
\hline 48 & 2 & rapid & $\mathrm{C}, \mathrm{G}, \mathrm{L}$ & $\mathrm{B}, \mathrm{Si}$ & shade & rare & 100 \\
\hline 49 & 3 & slow & B, S & Co, S & shade & much & 70 \\
\hline
\end{tabular}

${ }^{*} \mathrm{~B}$ : bamboo, $\mathrm{C}$ : conifer, $\mathrm{F}:$ fern, $\mathrm{G}:$ grass, $\mathrm{L}$ : latifoliate tree, $\mathrm{M}: \mathrm{moss}, \mathrm{R}:$ rice field, $\mathrm{S}:$ shrub

${ }^{*}{ }^{*} \mathrm{R}$ : rock, $\mathrm{B}$ : boulder, Co : cobble, $\mathrm{P}$ : pebble, G : granule, S : sand, F : fine sand, $\mathrm{Si}$ : silt, $\mathrm{Cl}$ : clay.

3 型のモードは両型とも $6 \sim 8 \mathrm{~mm}$ の甲幅範囲に認 められた (Fig. 4). 赤色 3 型, 赤色 2 型, および赤色 1 型のモードはそれぞれ16〜 18mm, 18〜20mm, 20〜22mm の甲幅範囲に認められた。一方，雌では， 茶色 2 型および茶色 3 型のモードはそれぞれ 6 ～ 8 $\mathrm{mm}, 8 \sim 10 \mathrm{~mm}$ の甲幅範囲に認められ, 赤色 3 型, 赤 色 2 型, および赤色 1 型のモードはそれぞれ12〜14 $\mathrm{mm}, 22 \sim 24 \mathrm{~mm}, 22 \sim 24 \mathrm{~mm}$ の甲幅範囲に認められ た. 茶色 1 型は雌雄とも広い甲幅範囲に出現した。

青色型生息域の雄では, 茶色 2 型および茶色 3 型の モードはともに $6 \sim 8 \mathrm{~mm}$ の甲幅範囲に認められ, 茶
色 1 型および茶色 4 型のモードはともに $14 \sim 16 \mathrm{~mm}$ の甲幅範囲に認められた (Fig. 5). 青色型は20〜22mm の甲幅範囲にモードが認められた。同地域の躍におい ても，茶色 2 型および茶色 3 型のモードはそれぞれ 6 〜 $8 \mathrm{~mm}, 8 \sim 10 \mathrm{~mm}$ の甲幅範囲に認められ, 茶色 4 型 および茶色 1 型のモードはそれぞれ12〜14mm, 14〜16mm 甲幅範囲に認められた。青色型のモードは 22〜24mm の甲幅範囲に認められた。

以上のように，赤色型が生息する地域では，甲幅が 小さいときには茶色 2 型および茶色 3 型の個体がもつ とも多く出現した。甲幅が $14 \mathrm{~mm}$ 前後になると両型に 


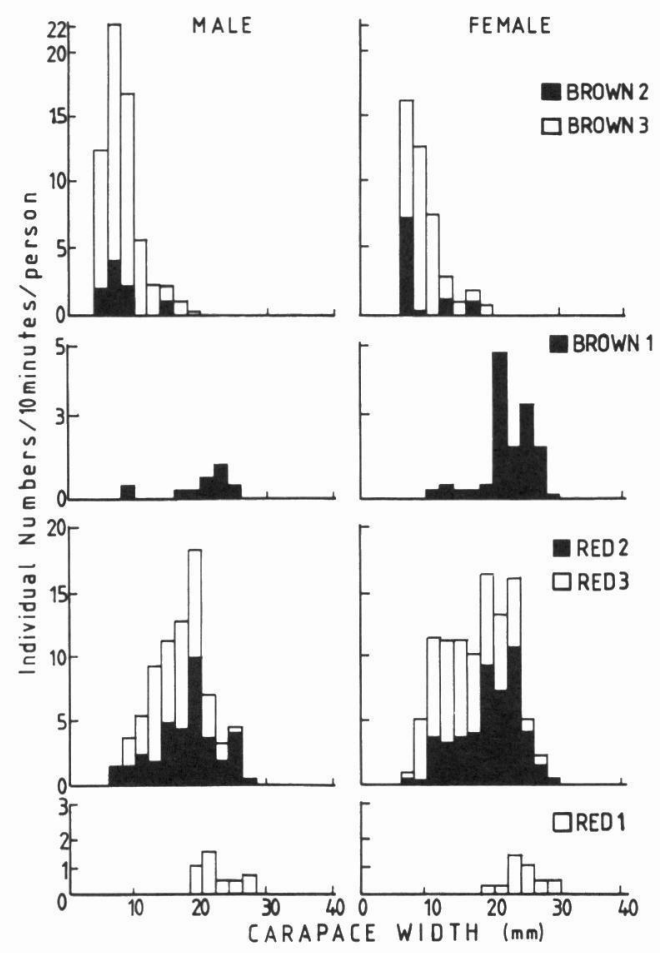

Fig. 4 Size frequency distribution of each color-type crab collected within the area where Red Type were distributed.

かわって赤色 3 型が多くなり，甲幅が $18 \mathrm{~mm}$ 前後では 赤色 2 型が多くなり，そして甲幅 $22 \mathrm{~mm}$ 前後では赤色 1 型が多くなる傾向がみられた。

この体色変化は，青色型が生息する地域でも同様の 傾向を示し, 甲幅が小さいときには茶色 2 型および茶 色 3 型の個体がもっとも多く, 甲幅 $14 \mathrm{~mm}$ 前後になる と両型にかわって茶色 4 型が多くなり, さらに, 甲幅 $20 \mathrm{~mm}$ 前後になると青色型が多くなった。茶色 1 型は 両地域とも小型個体から大型個体にわたって出現した.

\section{考察}

サワガニは甲幅 $4 \mathrm{~mm}$ 前後の稚ガニで睬化し, 孵化 時の体色には地域差はなくすべて淡黄褐色を呈してお り, 成長してはじめて, その地域特有の体色を呈する と報告されている(一寸木，1976)。鹿児島県に生息す るサワガニの体色は, 青色型, 赤色型, 茶色型の 3 型 に大別でき, 各体色型の甲幅組成から, 甲幅 $4 \mathrm{~mm}$ か
MALE

FEMALE

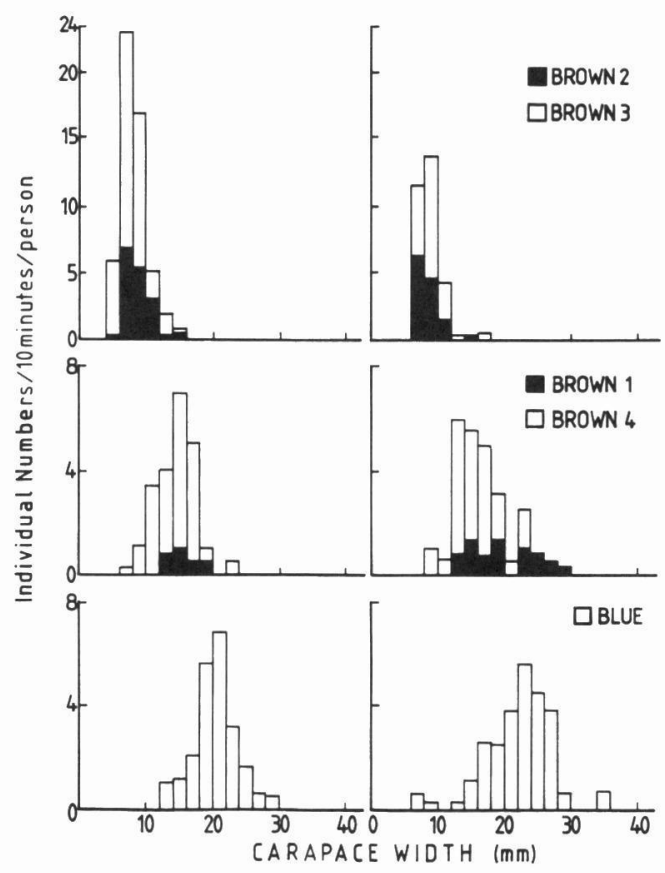

Fig. 5 Size frequency distribution of each color-type crab collected within the area where Blue Type were distributed.

ら $14 \mathrm{~mm}$ までの個体は茶色 2 型および茶色 3 型で, 甲 幅が $14 \mathrm{~mm}$ 以上になると青色型もしくは赤色型の体 色を呈するようになることが明らかにされた。したが って, 本種の体色変異は基本的に青色型と赤色型の 2 型のみであり，茶色型は小型個体の体色と考えられる。

嶺井（1976）および YAMAGUCHI \& TAKAMATSU （1980）は，本種の二次性徵は甲幅 $14 \mathrm{~mm}$ から $15 \mathrm{~mm}$ で完全に発現すると報告している。したがって, サワ ガニは二次性徴が発現する時期を境にして, 青色型も しくは赤色型の体色を呈するようになると考えられる. 茶色 4 型は, 青色型の生息する地域にのみ出現し, 茶色 $2 ， 3$ 型と青色型との中間型と考えられる.

北アメリカに生息するザリガニの一種 Orconectes immunis や, ルマエビ Penaeus japonicus では体色 変異は照度, 餌, 底質の色といった環境要因に起因す ることが知られている(KENT, 1901：三宅ら， 1968). しかしながら, 本研究では, 青色型の生息域と 赤色型の生息域の間で底質, 明るさ, 堆積物の量など 
の生息環境には大きな差が認められなかった。

甲殼類の多くはアスタキサンチンを主体とする色素 を含有しており，餌料中の $\beta$-カロテンやゼアキサンチ ンを変換してアスタキサンチンを蓄積すると言われて いる (TANAKA et al., 1976a, b ; Fox, 1976). サワ ガニについてもそのカロテノイド色素組成が研究され, アスタキサンチンが外殼の主色素であると報告されて いる(松野ら，1982）。本研究において青色型と赤色型 のカロテノイド色素組成を比較した結果，検体数は少 ないけれども，青色型では，材料となる $\beta$-カロテンが 豊富に蓄積されているにもかかわらず，アスタキサン チンやアスタキサンチン・モノエステル，アスタキサ ンチン・ジエステルがほとんど検出されないことが明 らかにされた.このことから, 赤色型においては $\beta$-カ ロテンからアスタキサンチンの代謝が予想されるが, 青色型においては $\boldsymbol{\beta}$-カロテンは吸収されるもののア スタキサンチンへの変換, 代謝が弱いか機能していな いことが示唆される。

赤色型と青色型の鹿児島県における地理的分布は, 薩摩半島では神之川水系, 甲突川水系および新川水系 の隣接する地域を境として, 大隅半島では肝属川水系 がある地域を境として，南北に明瞭に分かれることが 明らかになった。この分布の境となっている地域は, 約6300年前に発生した幸屋火砕流に起因する堆積物の 分布北限（日本第四紀学会編，1987）とほほ一致する。 今後は, サワガニ 2 体色型の分布を地史学的視点から 検討すると同時に, 両体色型の成長, 繁殖, 移動能力 などそれぞれの生態学的特性を明らかにする必要があ る.

\section{謝辞}

本研究を行うに際して, カロテノイド色素の分離分 析にあたりご指導ご助言をいただいた，鹿児島大学水 産学部海洋資源生物化学教室田中淑人博士に深謝致し ます。また，本論文をまとめるにあたり適切なご助言 をいたたいた，九州大学農学部動物学教室嶺井久勝博 士に感謝致します。さらに，英文部の校閲をして下さ った，鹿児島大学大学院留学生の Mr. J. D. RONQUIL. LO およびMr. M. I. SAIDに感謝致します.

\section{文献}

一寸木肇, 1976. サワガニ Geothelphusa dehaani (WHITE) の体色変異とその分布について（予
報)。甲殼類の研究, $7: 177-183$.

一寸木警，1980. 本州北部におけるサワガニ Geothelphusa dehaani (WHITE) の体色変異について（予 報)。甲殻類の研究, $10: 57-60$.

FOX, D. L., 1976. Animal biochromes and structural colours. Univ. California Press, L. A., $420 \mathrm{pp}$.

KENT, W. J., 1901. The colors of the crayfish. Amer. Nat., 35 : 933-936.

松野隆男・若狭義子・大久保雅啓, 1982. サワガニの カロテノイド. 日水誌, $48: 661-666$.

嶺井久勝, 1976. サワガニ, 清流に生きる，アニマ, $41: 10-15$.

三宅与志雄・石川雄介・星野暹，1968。餌料や底質の 違いによるクルマエビの体色変化. 岡山県水産試 験場事業報告書, 27-34。

NAKAJIMA, K. and T. MASUDA, 1985 . Identification of local population of freshwater crab Geothelphusa dehaani (WHITE). Bull. Japan. Soc. Sci. Fish., 51 : 175-181.

日本第四紀学会編, 1987. 日本第四紀地図. 東京大学 出版会, 東京, $1 \mathrm{p}$.

菅原恭一・蒲生重男, 1984。本州南部および四国にお けるサワガニ Geothelphusa dehaani (WHITE) の地方集団の分化について. 日本生物地理学会会 報, 39：33-37.

TANAKA, Y., H. MatsuguChI, T. KatAyAma, K. L. SIMPSON and C.O.CHICHESTER, 1976a. The biosynthesis of astaxanthin-XVI. The carotenoids in Crustacea. Comp. Biochem. Physiol., 54B : 391-393.

TANAKA, Y., H. MatSUGUCHI, T. Katayama, K. L. SIMPSON and C. O.CHICHESTER, $1976 \mathrm{~b}$. The biosynthesis of astaxanthin-XVIII. The metabolism of the carotenoids in the prawn, Penaeus japonicus BATE. Bull. Japan. Soc. Sci. Fish., 42 : 197-202.

YAMAGUCHI, T. and Y. TAKAMATSU, 1980. Ecological and morphological studies on the Japanese freshwater crab, Geothelphusa dehaani. Kumamoto J. Sci., Biol., 15 : 1-27.

890 鹿児島市下荒田四丁目50-20 鹿児島大学水産学部 鈴木廣志 